\title{
THE ANALYSIS OF COPRA FARMING REVENUE AND FACTORS INFLUENCING IT IN PALAM VILLAGE SUBDISTRICT OF NORTH TINANGKUNG, DISTRICT OF BANGGAI KEPULAUAN
}

\author{
Mohammad Ikhsan Diman ${ }^{1}$, Rustam Abdul Rauf ${ }^{2}, Y_{\text {ulianti Kalaba }}^{2}$ \\ 1) Student of Master Program at Department of Agribusiness of Tadulako University, Palu, \\ e-mail : iksan.diman26@gmail.com \\ ${ }^{2)}$ Lecturer and Researcher at Department of Agribusiness Faculty of Agriculture,Tadulako University, Palu.
}

\begin{abstract}
Coconut is one of the export commodities of sub sector farm which is best commodity of Central Sulawesi Province. This research aims to: (1) analize the income of copra farm in Palam Village of North Tinangkung District of Banggai Kepulauan Regency and (2) Analyze the factoedrs affect copra farm in Palam Villageof North Tinangkung District of Banggai Kepulauan Regency. The method usedwas survey and sample was selected using simple random. The number of the sample was 40 households. The research results indicate that.: (1) avarege of totalcost of copra farm was $\operatorname{Rp} 14.648 .819 .85 / 10.003 /$ coconut/1 time production. The aferage of acceptance of copra farm was Rp 20.502.768.75/1 time production with the average of sell price Rp 9.093.75/kg, so, the average income of copra farm was $\mathrm{Rp} 5.853 .948 .90 / 10.003$ coconut/1 time production and (2) F counted $=32.163$ with probability $\rho=0.000<0.05$ at $\alpha=5 \%$ proving that Null Hypothesis is rejected which means independent variable of self price $\left(X_{1}\right)$, production cost $\left(X_{2}\right)$ and copra production $\left(\mathrm{X}_{3}\right)$ simultaneusly affect copra farm income in Palam Village of Nort Tinangkung District of Banggai Kepulauan Regency determinant (R2) adjusted was 0.728 showing that income variation on copra farm $(\mathrm{Y})$ can be explained by independent variable of sell price $\left(\mathrm{X}_{1}\right)$, production cost $\left(\mathrm{X}_{2}\right)$, and copra production $\left(\mathrm{X}_{3}\right)$ was $72.8 \%$, whereas $27.2 \%$ explained by other factor excluded of the model. Partially the price sell and copra production positively affect and significant on copra farm income while production cost negatifely affect on confidence level of $95 \%$.
\end{abstract}

Key Words : Copra farm income, price sell, production cost.

\section{INTRODUCTION}

The potential of the state income from export product of Coconut in Indonesia is crucial considering its position as the largest coconut producent in the world. Indonesia is currently becoming one of the largest coconut producing countries with 3.8 million hectares of coconut plantation. With this larger area of land Indonesia produces 16.3 billion coconut in a year. Indonesia's foreign exchange from coconut products exports in 2012 was only USD 1.36 billion or $0.5 \%$ of Indonesia's total exports for the same year. In fact, by considering the export potential from coconut sector Indonesia can reach 85 trillion to 102 trillion per year, which is $3.9 \%$ to $4.2 \%$ of the total national export revenue (Mawardin and Aditya, 2015).

Central Sulawesi is one of the second largest coconut producing areas in Indonesia after North Sulawesi, causing the region to be given the slogan of "Bumi Nyiur". The word Bumi means land and Nyiur is coconut. The potential for coconut development in this area is quite large both from the aspect of cultivation, economy, and from the socio-cultural aspects. Coconut plant development gives a big contribution towrds economy of Central Sulawesi in general and Banggai Islands 
Regency in particular, especially for farmers' family income in that region. Processing of coconut business in Banggai Kepulauan Regency is generally still using technology that is not recommended such us the use of production inputs (pesticide fertilizers and other means) required to support the growth of coconut plants optimally, resulting an increasein quality and quantity of production which ultimately affects the increase in income and welfare of the Coconut farmers community in Banggai Kepulauan Regency. The productivity of coconut in Banggai Kepulauan Regency can be seen in Table 1 .

From the table 1 above, it can be seen that the area of crop yields with varying levels of production and productivity of coconut plants in 12 districts in Banggai Kepulauan District. Total planting area is $14,238.70$ hectares of coconut with production level of $10,830.75$ tons and the level of productivity of plants only reached 0.760 tons / ha. Bulagi sub-district has the highest level of productivity that reaches 0 . 855 tons / ha and Tinangkung Sub-district has the lowest productivity level which only reaches 0.658 tons / ha.

The productivity rate of the coconut plant shows that the average number of production in each sub-district with low productivity levels far below the productivity level of Central Sulawesi Province which reaches above 0.9 ton / ha. The productivity of coconut in North Tinangkung District can be seen in Table 2 .

Table1. Data on Coconut Area, Production and Productivity in Each Subdistrict at Banggai Kepulauan Regency

\begin{tabular}{clrrc}
\hline No & \multicolumn{1}{c}{ Subdistrict } & $\begin{array}{c}\text { Width Area } \\
\text { (Ha) }\end{array}$ & $\begin{array}{c}\text { Production } \\
\text { (Ton) }\end{array}$ & $\begin{array}{c}\text { Productivity } \\
\text { (Ton/Ha) }\end{array}$ \\
\hline 1 & Tinangkung & 942 & 619,86 & 0,658 \\
2 & North Tinangkung & 919,40 & 754,55 & 0.821 \\
3 & South Tinangkung & 1.776 & 1.488 & 0,838 \\
4 & Totikum & 2.127 & $1.520,06$ & 0,715 \\
5 & South Totikum & 359 & 293,51 & 0,817 \\
6 & Liang & 867 & 605,77 & 0,699 \\
7 & Central Peling & $2.091,35$ & $1.478,58$ & 0,707 \\
8 & Bulagi & 991 & 847 & 0,855 \\
9 & North Bulagi & 604 & 432,1 & 0,715 \\
10 & South Bulagi & 383,45 & 315,022 & 0,822 \\
11 & Buko & $2.475,50$ & $1.957,61$ & 0,791 \\
12 & South Buko & 703 & 518,69 & 0,738 \\
\hline \multicolumn{2}{r}{ Jumlah } & $14.238,70$ & $10.830,75$ & 0.760 \\
\hline
\end{tabular}

Source: Fixed Number Data (ATAP) Plantation Statistics of Banggai Kepulauan District, 2015.

Table2 . Width Area of Coconut, Production and Productivity of Coconut Based on Villages, in The Subdistrict of North Tinangkung

\begin{tabular}{llrrc}
\hline No & \multicolumn{1}{c}{ Village } & $\begin{array}{c}\text { Width Area } \\
\text { (Ha) }\end{array}$ & $\begin{array}{c}\text { Production } \\
\text { (Ton) }\end{array}$ & $\begin{array}{c}\text { Productivity } \\
\text { (Ton/Ha) }\end{array}$ \\
\hline 1 & Palam & 325 & 302,40 & 0,931 \\
2 & Luksagu & 128 & 85 & 0,664 \\
3 & Tatakalai & 33,40 & 28,75 & 0,861 \\
4 & Ponding-Ponding & 146 & 119,60 & 0,819 \\
5 & Lalong & 152,50 & 123,50 & 0,809 \\
6 & Bangpanga & 134,50 & 95,30 & 0,709 \\
\hline \multicolumn{1}{r}{ Jumlah } & 919,40 & 754,55 & 0,821 \\
\hline
\end{tabular}

Source: Fixed Number Data (ATAP) Plantation Statistics of Banggai Kepulauan District, 2015. 
Table 2. shows that Palam Village is one of the coconut production center villages in North Tinangkung subdistrict with contribution of coconut production reaching 302,40 tons from area of plant yield of 325 ha. The level of productivity of coconut crops in Palam Village shows that the number is quite high and reaches 0.931 tons / ha compared to other villages in the sub-district.

Low productivity is one of the major problems faced by coconut farmers in general and especially copra farmers in Palam Village. The low production of copra / ha / year production is caused (1) the coconut cultivation is still limited and without the addition of supporting material for the plant, (2) the composition of the coconut plant that is cultivated is $30 \%$ aged more than 50 years old, (3) Less attention is given to management aspect, (4) Plant pests and diseases, (5) Sources of planting materials (developed coconut varieties). In addition, price that tends to rise and fall, causing the farmers to neglect the development and growth of coconut.

Coconut sales price in the form of copra which tends to fluctuate causing uncertainty in giving maximum profit for copra farmers. Other products, such as coconut oil is also starting to be less desirable,because the community is now more interested in using palm oil. This phenomenon becomes an interesting issue to be further studied, especially to know the level of income that can be obtained by farmers from coconut products that are processed and sold in the form of copra and what factors influence it.

Problem Statement. Based on the background above, the main problem in this research can be formulated as follows:

1. How much copra revenuecan be obtained from Copra in Palam Village North Tinangkung sub district, District of Banggai Kepulaun.

2. What factors affect the revenue of copra business in Palam Village, North Tinangkung Sub-district, Banggai Kepulaun District?
Research Objective. The purposes of this study are as follows:

1. To analyze the amount of copra business revenue in Palam Village, North Tinangkung Sub-district, Banggai Kepulauan District.

2. To analyze factors affecting the copra business in Palam Village, North Tinangkung Sub-district, Banggai Kepulauan District.

Research Significance. The significance of this research, among others, is expected to be used as:

1. Input for farmers in an effort to increase their revenue from the copra business.

2. Information for local government, especially technical offices involved in coconut development projects and other stakeholders in formulating and establishing a policy in the development of coconut commodities.

\section{RESEARCH METHODS}

This is a descriptive research study, which presents description about facts obtained in the field where the data collection is conducted through survey method and direct observation in the field. Survey is done by collecting information systematically from respondents to understand and to know real condition in the field. Descriptive research seeks to find a proper and sufficient description of all activities, objects, processes, and humans (Natsir, 2014). The data collected from is processed through the tabulation of questionnaire data, administrating and analyzing data from the questionnaire which is further explained descriptively.

This research was conducted in Palam Village, North Tinangkung Subdistrict, Banggai Kepulauan Regency. The location of the study is determined purposively, on the basis of the consideration that Palam Village is one of the six villages located in the North Tinangkung District and it is also Situated in North Tinangkung Subdistrict 
and is the center of coconut production in accordance with statistical data obtained from Banggai Kepulauan District plantation in the year of 2014 (Table 2). This research was conducted from June 2016 until August 2016.

The population in this research is copra farmers, who live in Palam Village, North Tinangkung Sub-district, Banggai Kepulauan Regency. The number of farmers in Palam Village subdistrict of North Tinangkung is 200.The size of the sample determined that the number of samples taken at least as much as $10 \%$ of the population size as proposed by Singarimbun and Effendi (1989). In this study the samples were taken as much as $20 \%$ of the population and was done in siimple random sampling so there were 40 total number of respondents.

The data in this research consists of primary data and secondary data. Primary data were obtained through observation and direct interview with selected respondent farmers, using Questionaire, while secondary data were obtained from relevant agencies and literature relevant to the purpose of this study.

Revenue Analysis. In answering the main objective of this study, the obteined data is analyzed descriptively and presented in the form of table, and this process is continued by referring to cost calculation, income and revenue. According Soekartawi (1995), farm revenue Is the difference between the amount of revenue and the amount of costs. The formula used is as follows:

$$
\pi=\mathrm{TR}-\mathrm{TC}
$$

Where

$\pi=$ Copra revenue $(\mathrm{Rp})$

$\mathrm{TR}=$ Total revenue of copra business $(\mathrm{Rp})$

$\mathrm{TC}=$ Total cost of copra business $(\mathrm{Rp})$

While to know the income of the farming, the obtained production is multiplied by the selling price:

$$
\mathrm{TR}=\mathrm{Q} \times \mathrm{Pq}
$$

Where:

$\mathrm{TR}=$ Total revenue of copra business $(\mathrm{Rp})$
$\mathrm{Q}=$ Total copra production sold $(\mathrm{Kg})$

$\mathrm{Pq}=$ Price per unit of production $(\mathrm{Rp})$

Next to know the amount of cost incurred, the following calculation is used:

$$
\mathrm{TC}=\mathrm{FC}+\mathrm{VC}
$$

Where

$\mathrm{TC}=$ Total Cost

$\mathrm{FC}=$ Fixed Cost

VC = Variable Cost (Variable Cost)

Multiple Linear Regression Analysis. Responding to the second objective of this research namely analyzing factors affecting copra revenue, structural equations are used multiple linear regression analysis which is transformed into logarithmic form of the following model:

$$
\mathrm{Y}=\beta \mathrm{o}+\beta 1 \mathrm{X} 1+\beta 2 \mathrm{X} 2+\beta 3 \mathrm{X} 3+\mu
$$

Where:

$\mathrm{Y}=$ Copra revenue $(\mathrm{Rp})$

Bo = Intercept

B1- $\beta 3=$ The estimated quantity (1 to 3 )

$\mathrm{X} 1=$ Copra Sale Price $(\mathrm{Rp} / \mathrm{kg})$

$\mathrm{X} 2=$ Production Cost $(\mathrm{Rp})$

$\mathrm{X} 3=$ Production $(\mathrm{Kg})$

$\mathrm{M} \quad=$ Pitfalls

The precision of the above equation model is measured by the coefficient of double determination (R2). In a study or observation, it should be seen to what extent the model that is formed can explain the actual conditions, using the formula as follows:

$$
R 2=\frac{\text { The sum squares of Regression }}{\text { Total of Squares }}
$$

If the value of the coefficient determination given the symbol R2 close to the number 1 , then the independent variable closer to the relationship with the dependent variable so it can be concluded that the use of the model can be justified. In addition the coefficient of determination (R2) is used to measure the proportion (Percentage) of the amount of $\mathrm{Y}$ described by the regression model or to measure the contribution of the variable $\mathrm{X}$ to variable $\mathrm{Y}$. 
Operational Concepts. The operational concepts used in the research are as follows:

1. Respondents are coconut farmers who live in Palam Village, North Tinangkung Sub-district, Banggai Kepulauan Regency, as well as copra producers, in this case the farmers produce and sell their products in the form of copra.

2. Laborsarethose adult men and women, used in the process of producing copra that is stated in the HOK.

3. Production cost shall be all expenditures used, in a production process of copra production business, written in rupiah.

4. Fixed costs are those costs that are relatively unchanged or not dependent on changes in production volume expressed in rupiah.

5. Variable costs are costs that are changed and used up in one production process, expressed in rupiah.

6. Production price is the copra selling price applicable at farmer level, expressed in Rupiah per kg.

7. Revenue is the difference between receipts and production costs expressed in rupiah.

8. Income is the amount of money received by the copra farmer and is the the result of the multiplication of production and price of production per unit, expressed in rupiah.

9. Production is the amount of copra produced by farmers in one harvest period, expressed in $\mathrm{kg}$.

10. Transportation costs are costs incurred by farmers in the marketing process Which consists of transportation costs and labor costs for loading and unloading, expressed in Rupiah per kg.

11. The data collected and analyzed in this research is data during one period of copra making at the time of this research.

\section{RESULTS AND DISCUSSION}

Geographical Location. Palam Village is one of 6 villages located in North Tinangkung
District of Banggai Kepulauan Regency. Administratively it has an area of 43.65 $\mathrm{km} 2$. The boundaries of Palam Village are as follows:

- North by the Maluku Sea

- South is bordered by Salangano Village

- The east is bordered by Kombutokan Village

- The west is bordered by Luksagu Village

Palam Village is included in the administrative area of North Tinangkung Sub-district, Banggai Kepulauan Regency, Central Sulawesi Province.

Income of of Kopra. Farmers produce an average copra of $2,254.60 \mathrm{~kg} / 10,003$ coconut / 1 time of production. The average income of copra business is $\operatorname{Rp} 20,502,768.75$ / 1 time of production, with an average selling price of $\mathrm{Rp} \mathrm{9,093.75} \mathrm{/} \mathrm{kg}$. The income of the copra farming is the multiplication of copra production with the price obtained by farmers. The income depends on the amount of production earned by the selling price on the market, if the amount of production obtained increases then the amount of income also increases, so too the price obtained in the market will greatly determine the farmers' income.

Total Cost of Copra Farming. The total cost of the copra consists of fixed and variable costs. Fixed costs are relatively fixed and continued to be incurred even if production is in small amounts. So the cost is not dependent on the size of production obtained. These fixed costs include the cost of village taxes and depreciation. Fixed costs (variable costs) are costs that are influenced by the obtained production. The variable cost of copra farming in a month of production is the cost of labor, coconut cost and the cost of transportation.

Average cost of copra farmers is Rp 80,832.40 / 10,003 coconuts / 1 time of production. The average variable cost incurred by the copra farmers is Rp 14.567.987,45 / 10.003 coconut / 1 time production. The average total cost of the copra farming is Rp 14,648,819.85 / 10,003 coconuts / 1 time production. 
Revenue of Copra Farming. The amount of copra revenue earned by farmers is the difference between the receipt and the amount of expenditure or. Costs, either in the form of fixed costs or variable costs. The amount of copra income can be seen in Table 3.

Table 3 shows that the average revenue of copra farming in Palam Village is $\mathrm{Rp} 5.853 .948,90$ / 10.003 coconuts / 1 time of production. The amount of copra revenue in Palam Village per 1 time production amounted to $\mathrm{Rp} 5,853,948.90$ this indicates that the revenue earned by copra farmers in Palam Village per 1 time production is above UMR at Banggai Kepulauan Regency that is $\mathrm{Rp} 1,800,000.00$ per month, so it can be concluded that revenue of Copra farming is sufficient to meet the needs of copra farmers.

Factors Affecting Copra Revenue. Some factors that affect revenues of copra farming in Palam Village North Tinangkung subdistrict include selling price (X1), production cost (X2), and copra production (X3). Analysis of factors that affect the revenue of the copra farming in Palam Village, Tinangkung Utara Subdistrict, Banggai Kepulaun Regency uses Cobb-
Dauglas production function, where the dependent variable (dependent variable) $\mathrm{Y}$ is the copra revenue.Anova of the factors that affect the income of copra business in Palam Village, Tinangkung Utara Sub-district, Banggai Kepulaun Regency is as follows:

Table 3. Revenue of Copra Farming in Palam Village

\begin{tabular}{|c|c|c|}
\hline \multirow[t]{3}{*}{ No } & Items & $\begin{array}{c}\text { Copra Farming } \\
\text { (1 Time Production) }\end{array}$ \\
\hline & $\begin{array}{l}\text { Average production of } \\
\text { Copra }(\mathrm{kg})\end{array}$ & $2.254,60$ \\
\hline & Average prices $(\mathrm{Rp} / \mathrm{kg})$ & $9.093,75$ \\
\hline \multirow[t]{5}{*}{1} & Revenue & $20.502 .768,75$ \\
\hline & Cost: & \\
\hline & a.Fixed Cost: (FC) & \\
\hline & Depreciation (Rp) & $70.380,90$ \\
\hline & Tax/Year (Rp) & $10.451,50$ \\
\hline \multirow[t]{7}{*}{2} & Subtotal & $80.832,40$ \\
\hline & b.Variable Cost: (VC) & \\
\hline & Labor (Rp) & \\
\hline & b.Variable Cost: (VC & \\
\hline & Labor (Rp) & $1.720 .987,45$ \\
\hline & Coconut (Rp) & $12.503 .125,00$ \\
\hline & Transportation cost (Rp) & $343.875,00$ \\
\hline 3 & Subtotal & $14.567 .987,45$ \\
\hline 4 & Total Cost $(2+3)(\mathrm{TC})$ & $14.648 .819,85$ \\
\hline 5 & Revenue $(1-4)$ & $5.853 .948,90$ \\
\hline
\end{tabular}

Source: Primary Data After Being Processed, 2016.

Table 4. Anova Factors That Influence Copra Farming at Palam Village North Tinangkung Subdistrict, Banggai Kepulaun Regency

\begin{tabular}{cccccc}
\hline \multicolumn{1}{c}{ Description } & $\mathrm{Db}$ & Sum of Squares & Middle Square & $\mathrm{F}_{\text {count }}$ & Probability \\
\hline Regression & 3 & 22,952 & 7,651 & 32,163 & 0,000 \\
Residual & 36 & 8,563 & 0,238 & & \\
\hline \multicolumn{1}{c}{ Total } & 39 & 31,516 & & & \\
\hline
\end{tabular}

Source: Primary Data After Being Processed, 2016.

Table 5. Multiple Regression Coefficients from Several Factors That Affect Revenue of Copra Farming in Palam Village North Tinangkung, Banggai Kepulaun Subdistrict

\begin{tabular}{lcc}
\hline \multicolumn{1}{c}{ Description } & Regression Coefficient & probability \\
\hline Konstanta & 14,703 & \\
Selling price & 0,436 & $0,000^{* *}$ \\
Production cost & $-0,552$ & $0,000^{* *}$ \\
Copra production & 0,407 & $0,000^{* *}$ \\
\hline
\end{tabular}

Adjusted determinant Coefficient $\left(\mathrm{R}^{2}\right) 0,728$

** significantat $\alpha=5 \%$ 
Table 4 shows $F_{\text {count }}=32,163$ with probability $\mathrm{p}=0,000<0,05$ at $\alpha=5 \%$ that proves that null hpothesis is rejected, this also means that that independent variable of selling price (X1), production cost (X2), and copra production (X3) simultaneously affects the revenu of the copra farming in Palam Village, North Tinangkung Subdistrict, Banggai Kepulaun Regency.

The adjusted determinant coefficient $\left(\mathrm{R}^{2}\right)$ of 0.728 indicates that the variation of copra revenue $(\mathrm{Y})$ can be caused by the independent variables of selling price (X1), production cost (X2) and copra production (X3) of $72.8 \%$, while $27,2 \%$ is caused by other factors that are not included in the model such as climate factors, etc.The influence of each factor influencing the copra farming revenue in Palam Village, North Tinangkung Sub-district, Banggai Kepulaun Regency is as follows:

Selling Price. The selling price has a positive influence and a real effect on copra revenue where probability $\rho=0,000<0.05$ two-way test at the $95 \%$ level of significance. The regression coefficient of 0.436 can be interpreted that an increase of $1 \%$ copra selling price can develop revenue of copra farming by $0.436 \%$, assuming other factors are considered constant. This research is relevant to Mawardati (2015) research findings which conclude that the selling price is one of the factors that have significant influence towardsrevenue of pinang farming in Sawang subdistrict, North Aceh regency. Prices also play a very significant effect on the revenue of potato farming in Bukit Subdistrict, Bener Meriah Regency (Mawardati, 2013).

The results of this study are also relevant to the results of previous research conducted by Syanti et al (2014) that concluded the selling price has a positive and significant effect on the revenue of farmers in KUD Lingkung Aur II Pasaman Subdistrict Pasaman Barat, which suggested that if the higher the selling price of oil palm TBS Then the higher the revenue will be received by farmers. The result of this research is also supported by result of Tumoka's research (2013), which stated that variable of price equal to 10,923 is bigger than t-table value of 2,660 with significant level of $0,01<0,05$, therefore $\mathrm{H}_{0}$ is rejected which means tomato price significantly influence tomatoes farmer's earnings in West Kawangkoan District.

Production Cost. Production costs is the cost derived from the provision of raw materials and the costs incurred to produce raw materials to become ready-made materials for sale (Khusumah et al, 2009).

Production costs have a negative and real effect on copra revenus, where the probability $\rho=0,000<0.05$ two-way test at $95 \%$ level of significance. The regression coefficient of -0.552 can be interpreted that any increase of production cost by $1 \%$ can decrease copra farming revenue by $0.552 \%$, assuming other factors are considered constant. This research is relevant to the previous findings by Zikrina, et al., (2011) who found that the production cost has a significant effect on the revenue of organic rice farmers.

The results of this study indicated that production costs played an important role in increasing revenue, this means if cost of production is greater, it will further decrease revenue. This research is in line with the previous investigation by Malik (2015) where results of analysis showed that the cost of producing fried onions has a regression coefficient of 0.825 which means that each additional production cost of $1 \%$ will decrease revenue by $0.825 \%$ with the assumption that other variables are considered constant.

Copra Production. Copra production has a positive and real effect on copra revenue, where the probability of $\rho=0,000<0.05$ a two-way test at a $95 \%$ level of significance. Regression coefficient is 0.407 that means any increase of copra production by $1 \%$ can increase the copra farming revenue by $0.407 \%$, assuming other factors are considered constant. This research is relevant to Mawardati research (2015) 
who found that production is one of the factors that have a very significant effect to Pinang farming revenue in Sawang District, North Aceh Regency. Production also playa very significant effect on the revenue of potato farming in Bukit Subdistrict, Bener Meriah Regency (Mawardati, 2013). Furthermore Zikrina, et al. (2011) explained in his research that production is a factor that influences the revenue of organic rice farmers in Serdang Berdagi District. In this research, the result of partial influence test using $t$ test showed that organic rice production has significant effect to organic rice farmer revenue, where the value of organic rice production coefficient of 6293,17 indicates if organic rice production increased $1 \mathrm{~kg} / \mathrm{ha}, 6,293.17$ / ha.

\section{CONCLUSIONS AND RECOMMENDATIONS}

\section{Conclusion}

Based on research results and discussion, it can be concluded that:

1. The average total cost of the copra farming in Palam Village, North Tinangkung Subdistrict is Rp14.648.819,85 / 10.003 coconut / 1 time of production. The average revenue of copra business is Rp 20,502,768.75 / 1 time production, with an average selling price of $\mathrm{Rp} 9,093.75$ / $\mathrm{kg}$, so that the average

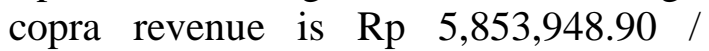
10,003 coconut / 1 time of production.

2. Variable selling price (X1), production cost (X2), and copra production (X3) simultaneously (together) affect the revenue of copra business in Palam Village, Tinangkung Utara Sub-district, Banggai Kepulaun Regency. Partially selling price and copra production have positive and real effect to copra income while production cost negatively at $95 \%$ level of significance.

\section{Recommendations}

Based on the conclusions of this reserch, there some suggestions need to be considered as follows :

1. In order to increase the revenue of the copra farming in Palam Village, the farmers need to take into account the use of production inputs such as the number of coconuts and labor.

2. In order to increase the revenue of the copra business in Palam Village, the farmers should be more efficient at the use of the production cost incurred, so that it can generate greater income.

\section{REFERENCES}

Khusumah, Usmandan Amalia Suzanti, 2009. Analysis of The Effect of Production Cost and Sales of Clean Water to Net Income (Case Study PT. PDAM Tirtanadi). J. Akuntansi FE UNSIL, Vol. 4, No 1.

Malik, Shintami R., 2015. Factors Affecting the Income of Fried Onion Industry in Palu City. Tesis, Master Program of Agribusiness Postgraduate Program of Tadulako University, Palu.

Mawardati, 2013. Analysis of Factors Affecting the Revenue of Potato Farming in BenerMeriah District, Aceh Province. J. Agrium, Vol. 10 (2) : 38-42.

Mawardati, 2015. Analysis of Factors Affecting the Income of Pinang Farming District of Sawang District, North Aceh District. J. Agrisep Vol. 16 (1) : 61 - 65.

Mawardin M.S. danAdiya K., 2015. Save The Tri Of Live Potential of Indonesian Coconut Sector. Jawa Mediasindo Lestari, Bogor.

Mubyarto, 1991. Introduction to Agricultural Economics. LP3ES. Jakarta

Natsir, M., 2014. Research methods. Ghalia Indonesia, Bogor.

Singarimbun, M. dan Effendi, S. 1989. Survey Research Methods. Institute for Educational Research and Economic and Social Information, Jakarta.

Soekartwi, 1995. Analysis of Farming. University of Indonesia, Jakarta. 
Syanti, Yulihardi, dan Dina Amaluis. 2014. The Influence Of Production Cost And Selling Price Of Fresh Fruit Bunches (TBS) Of Palm Oil To Farmer's Income In KUD LingkungAur in Pasaman SubDistrict Pasaman Barat Regency. Vol. 1 (1) (2014): 48th Graduation Journal Student of Economics Education Program.

Tumoka, Nova, 2013. Analysis of Tomato Farmer Production Income In Kawangkoan Barat District Minahasa District. J. EMBA 345 Vol. 1 (3) : 345-354.

Zikrina, Mozart, B., Darus, dan Dhalil, D., 2011. Factors Affecting Organic Farmer Revenue in Serdang Bedagai District (Case Study: LubukBayas Village, KecamatanPerbaungan). E- jurnal, : 1 - 10. 